\title{
DERIVATION OF SCREENING BENCHMARKS FOR DIETARY METHYLMERCURY EXPOSURE FOR THE COMMON LOON (GAVIA IMMER): RATIONALE FOR USE IN ECOLOGICAL RISK ASSESSMENT
}

\author{
David C. Depew, ${ }^{*} \dagger$ Niladri Basu, $\ddagger$ Neil M. Burgess, $§$ Linda M. Campbell, $\nmid$ David C. Evers, $\|$ \\ Keith A. Grasman,\# and Anton M. Scheuhammer $\dagger$ \\ $\dagger$ Department of Biology and School of Environmental Studies, Queen's University, Kingston, Ontario, Canada \\ tDepartment of Environmental Health Science, University of Michigan, Ann Arbor, Michigan, USA \\ $\S$ Ecotoxicology and Wildlife Health Division, Environment Canada, Mount Pearl, Newfoundland and Labrador, Canada \\ ||Biodiversity Research Institute, Gorham, Maine, USA \\ \#Department of Biology, Calvin College, Grand Rapids, Michigan, USA \\ $\dagger †$ National Wildlife Research Centre, Environment Canada, Ottawa, Ontario, Canada
}

(Submitted 5 April 2012; Returned for Revision 3 May 2012; Accepted 20 June 2012)

\begin{abstract}
The current understanding of methylmercury (MeHg) toxicity to avian species has improved considerably in recent years and indicates that exposure to environmentally relevant concentrations of $\mathrm{MeHg}$ through the diet can adversely affect various aspects of avian health, reproduction, and survival. Because fish-eating birds are at particular risk for elevated MeHg exposure, the authors surveyed the available primary and secondary literature to summarize the effects of dietary $\mathrm{MeHg}$ on the common loon (Gavia immer) and to derive ecologically relevant toxic thresholds for dietary exposure to $\mathrm{MeHg}$ in fish prey. After considering the available data, the authors propose three screening benchmarks of $0.1,0.18$, and $0.4 \mu \mathrm{gg}^{-1}$ wet weight $\mathrm{MeHg}$ in prey fish. The lowest benchmark $\left(0.1 \mathrm{~g} \mathrm{~g} \mathrm{~g}^{-1}\right.$ wet wt $)$ is the threshold for adverse behavioral impacts in adult loons and is close to the empirically determined no observed adverse effects level for subclinical effects observed in captive loon chicks. The remaining benchmarks $\left(0.18\right.$ and $0.4 \mu \mathrm{g} \mathrm{g}^{-1}$ wet wt) correspond to $\mathrm{MeHg}$ levels in prey fish associated with significant reproductive impairment and reproductive failure in wild adult loons. Overall, these benchmarks incorporate recent findings and reviews of $\mathrm{MeHg}$ toxicity in aquatic fish-eating birds and provide the basis for a national ecological risk assessment for Hg and loons in Canada. Environ. Toxicol. Chem. 2012;31:2399-2407. (C) 2012 SETAC
\end{abstract}

Keywords-Mercury Birds Risk assessment Toxicity

\section{INTRODUCTION}

The assessment of health risks to piscivorous birds associated with exposure to methylmercury $(\mathrm{MeHg})$ has been an area of active research for nearly 30 years [1]. Early studies tended to focus on gross clinical symptoms related to $\mathrm{MeHg}$ toxicity, such as mortality and gross motor dysfunction and reproductive failure [2,3], and were in large part driven by the obvious impacts of point-source $\mathrm{Hg}$ contamination ([4,S1]; all S-numbered references may be found online in the Supplemental Data). More recently, increasingly subtle yet biologically and ecologically important effects of $\mathrm{MeHg}$ exposure have been documented in a variety of piscivorous bird species including adverse effects on behavior and neurochemistry, and on biochemical and immunological function [5-8,S2-S4]. These more recent studies reflect both the development of tools and approaches to assess highly sensitive toxicological endpoints as well as the recognition that atmospherically transported $\mathrm{Hg}$ can result in contamination of sensitive aquatic ecosystems [9]. Consequently, the potential for adverse effects on piscivorous birds exposed to $\mathrm{MeHg}$ through their diet may be greater than previously anticipated [10].

Extensive ecotoxicological work since the early 1990s has established the common loon (Gavia immer) as an important avian indicator for $\mathrm{MeHg}$ exposure and effects in North

All Supplemental Data may be found in the online version of this article.

* To whom correspondence may be addressed (depewd@gmail.com).

Published online 2 August 2012 in Wiley Online Library (wileyonlinelibrary.com)
America [11-18,S5-S9]. Common loons are widely distributed geographically, are long lived, and feed preferentially on small fish (10-15 cm in size) from lakes within established territories (mean 70 ha [19]). These characteristics make this species an ideal indicator of $\mathrm{MeHg}$ contamination and exposure at local and continental scales [20]. Consequently, the common loon has recently been selected by the U.S. Environmental Protection Agency (U.S. EPA) National Health and Environmental Research Laboratory (NHEERL) as the focal species for development of ecological risk assessment frameworks linked to population models [21] and as the primary avian receptor for a national ecological risk assessment for $\mathrm{MeHg}$ under the Mercury Science Program of Environment Canada's Clean Air Regulatory Agenda [22].

Despite evidence that anthropogenic $\mathrm{Hg}$ emissions have been declining generally over the past few decades, concern for adverse effects on piscivorous fish and wildlife has increased in recent years. This is based on reports that $\mathrm{MeHg}$ levels appear to be increasing both in piscivorous fish and in wildlife at various locations across North America [13,23-25]. As a result, a timely review and synthesis of the literature on the common loon is appropriate. Recent comprehensive reviews of the effects of $\mathrm{MeHg}$ in wildlife have been provided by Wolfe et al. [26] and Shore et al. [27]. It is not our intent to revisit these reviews, rather, we seek: (1) to summarize the scope and magnitude of adverse effects of $\mathrm{MeHg}$ exposure documented in common loons to date; (2) to derive, using published models, dietary $\mathrm{MeHg}$ levels associated with the documented adverse effects; and (3) to derive screening benchmarks for dietary $\mathrm{MeHg}$ exposure for use in ecological risk assessment for the common loon. 


\section{MATERIALS AND METHODS}

For most wildlife species, screening benchmarks are often based on the empirically derived no observed adverse effects level (NOAEL [28]), and compilations of wildlife benchmarks are available in the literature (for example, [29]). However, the availability (or lack thereof) of species-specific data has necessitated the use of interspecies extrapolation or application of uncertainty factors [28,29]. This approach has recently been questioned when suitable data exist for a given species [30]. Moreover, for some contaminants, such as $\mathrm{MeHg}$, it is apparent that substantial interspecies variability in sensitivity exists among avian species [27] and further underscores the added uncertainty when conversion or uncertainty factors are employed.

Laboratory studies to determine empirically the NOAEL and lowest observable adverse effect level (LOAEL) concentrations are difficult to conduct with the common loon, because adult birds do not survive well in captivity (http://bna.birds.cornel1.edu/bna/species/313), and much of the literature on common loons and $\mathrm{MeHg}$ exposure is derived from field studies $[12,15,17, \mathrm{~S} 1, \mathrm{~S} 5-\mathrm{S} 8, \mathrm{~S} 10]$. When such studies examine the potential effects of $\mathrm{MeHg}$, they are generally correlative in nature but endeavor to control or account for potential confounding factors such as coexposure to other contaminants [16], anthropogenic disturbances (e.g., flooding or recreational activity $[\mathrm{S} 1, \mathrm{~S} 11])$, nest predation $[\mathrm{S} 7, \mathrm{~S} 12, \mathrm{~S} 13]$, or prey availability $[31,32, \mathrm{~S} 5, \mathrm{~S} 13]$ that may affect interpretation of the results. Our approach in the present study considers all available qualified toxicity data plus their measures of variability to derive ecologically relevant screening benchmarks.

\section{Relevant literature and establishment of benchmark categories}

We have reviewed the available primary and secondary literature to identify suitable studies for derivation of ecologically relevant screening benchmarks for the common loon. Studies included both field-based surveys and observational studies on breeding adults and chicks from various regions in North America and a series of papers documenting captive feeding studies with loon chicks (raised from egg to 105 days posthatch) over a period of several years (1999, 2000, and 2003; see Kenow et al. [S2-S4,S14-S16]) at the U.S. Geological Survey's Upper Midwest Environmental Sciences Center in LaCrosse, Wisconsin, USA. Although most sources have been published in the peer-reviewed literature, technical reports listing relevant endpoints from governmental agencies and the Biodiversity Research Institute were also evaluated.

Adverse effects were categorized by ecological relevance and severity as judged by the authors (Table 1) following the framework of Suter [28]. We considered population-level or individual-level effects to be the most important for deriving screening benchmarks in an ecological context. Mortality, survival, growth, and reproduction constitute endpoints that we considered to be highly relevant to the survival and recruitment of young birds and thus to population dynamics (Table 1). Although the interpretation of the influence of adult mortality and survival on population dynamics is relatively straightforward, the importance of decreased growth rates or reproductive impairment may be less clear. Slower growth rates are linked to a decreased likelihood of chick survival [33] and decreased avian productivity (defined as the number of fledged chicks per territorial adult pair per year [34]) and may impact population stability if productivity is insufficient to balance adult mortality [35].
Table 1. Classification of relevant toxicological endpoints by ecological endpoint for the common loon ${ }^{\mathrm{a}}$

\begin{tabular}{ll}
\hline Ecological endpoint & Toxicological endpoint \\
\hline Survival & Survival \\
& Mortality \\
Growth & Growth \\
& Body mass \\
Reproduction & Productivity \\
Behavioral & Egg hatching success \\
& Altered behavioral patterns \\
& Altered activity budgets \\
Subclinical & Impaired motor co-ordination \\
& Altered glutathione metabolism \\
& Oxidative stress \\
& Antibody suppression \\
& Lymphoid depletion \\
& Altered neurochemical receptor levels \\
& Altered corticosterone
\end{tabular}

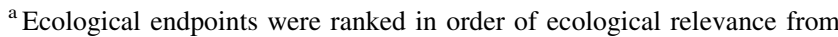
highest (survival) to lowest (subclinical) by the authors following the framework of Suter [28].

Effects such as altered behavioral activity and changes in neurochemistry, biochemistry, or immune function are potentially more sensitive toxicological endpoints than clinical effects at the individual level; however, quantitative relationships between these endpoints and individual- or populationlevel impacts are generally not well established, particularly for wildlife species [36]. For example, a dose-response relationship between dietary $\mathrm{MeHg}$ exposure and impaired immune function is difficult to link quantitatively to impacts on disease susceptibility or survival in free-living populations because sick or dead birds from a specific study population are infrequently recovered by researchers. Nevertheless, it is recognized that these subtle endpoints may have cascading effects that ultimately do affect population-level processes [37], and their potential importance to predictive ecotoxicology is likely to increase [36].

\section{Derivation of benchmark thresholds}

We evaluated the relevance and appropriateness of each selected study toward deriving a screening benchmark. Many of the selected publications have developed preliminary criteria (NOAEL, LOAEL) for various measures of $\mathrm{MeHg}$ exposure in loons. The LOAELs for loon chicks were estimated to be $3 \mu \mathrm{g} \mathrm{g}^{-1}$ wet weight in blood, $40 \mu \mathrm{g} \mathrm{g}^{-1}$ wet weight in feathers [S6,S7], $>1.3 \mu \mathrm{gg}^{-1}$ wet weight in eggs [S8], and $0.4 \mu \mathrm{g} \mathrm{g}^{-1}$ wet weight in the diet [S2-S4]. The use of different measurement matrices has both advantages and disadvantages. On the one hand, loon tissues and blood may provide a more accurate assessment of adverse effects because they integrate $\mathrm{Hg}$ exposure over all dietary sources and distinct time periods [S7]. Similarly, egg $\mathrm{Hg}$ burdens are directly related to maternal dietary exposure and can be readily linked to developmental and reproductive toxicity [S16]. On the other hand, lake-specific fish $\mathrm{Hg}$ data are generally more readily available and comparatively simpler to acquire compared with loon tissue, blood, or eggs. A screening benchmark based on $\mathrm{Hg}$ concentration in prey fish would be beneficial for providing an economical and defensible screening tool for assessing potential impacts of dietary $\mathrm{MeHg}$ exposure to the common loon.

Studies from various regions in North America have indicated that loon blood $\mathrm{Hg}$ levels reflect recent dietary exposure during the breeding season and are positively correlated to $\mathrm{Hg}$ 
levels in prey in the nesting lake $[11,15,17]$. For the purposes of this review, we assume that total $\mathrm{Hg}$ measured in fish of the size typically consumed by loons (10-15 cm [19]) is entirely $\mathrm{MeHg}$ $[25,38]$ and that, for loon blood, muscle, brain, and egg contents, measured total $\mathrm{Hg}$ is equivalent to $\mathrm{MeHg}$ [S15]. Unless measured directly, prey fish $\mathrm{MeHg}$ concentration associated with the threshold criteria were estimated using the following steps. First, for $\mathrm{MeHg}$ criteria developed for brain tissue, we used equations developed by Kenow et al. [S15] to convert from brain $\mathrm{Hg}$ to juvenile loon blood $\mathrm{Hg}$.

$$
\begin{aligned}
\log \left(\operatorname{Hg}_{\text {Blood }}\right) & =0.726+1.059\left[\log \left(\operatorname{Hg}_{\text {Brain }}\right)\right] \\
r^{2} & =0.97, n=17
\end{aligned}
$$

Second, for criteria developed with egg $\mathrm{Hg}$ levels, we used the equation developed by Evers et al. [S8] to convert egg $\mathrm{Hg}$ to female blood $\mathrm{Hg}$.

$$
\begin{aligned}
\text { Blood } \mathrm{Hg}_{\text {Female }} & =0.2238+1.5544\left[\mathrm{Hg}_{\mathrm{Egg}}\right] \\
r^{2} & =0.79, n=108
\end{aligned}
$$

Third, for criteria developed using chick blood $\mathrm{Hg}$, we converted these to female blood using the equations developed by Evers et al. [15].

$$
\begin{aligned}
\text { Blood } \mathrm{Hg}_{\text {Female }} & =1.102286+0.464995\left[\ln \left(\text { blood } \mathrm{Hg}_{\text {chick }}\right)\right] \\
r^{2} & =0.64, n=80, \text { for chicks }<28 \mathrm{~d} \text { old }
\end{aligned}
$$

Lastly, for threshold levels converted to female blood $\mathrm{Hg}$ (steps $1-3$ ), we calculated prey fish $\mathrm{Hg}$ using the relationship developed by Evers et al. [15] for fish in the 10 to $15 \mathrm{~cm}$ size range.

$$
\text { Fish } \mathrm{Hg}=\left(\text { Blood } \mathrm{Hg}_{\text {Female }}-0.5079\right) / 10.644, r^{2}=0.51
$$

These steps allowed us to convert among different measurement matrices to derive an estimate of dietary $\mathrm{MeHg}$ exposure in preferred prey that brackets the indicator prey size chosen for a subsequent national-scale ecological risk assessment. When possible, we also calculated the effective concentration for $20 \%$ (EC20) and 50\% (EC50) using regression models provided in the source document (as recommended by Allard et al. [30]). The EC20 was chosen to remain consistent with the average reduction in endpoint parameters $(\sim 20 \%)$ observed in dietary exposure tests of avian reproduction for terrestrial risk assessment of pesticides [39] and because the EC20 often approximates the LOAEL in field studies [40].

Several studies reported only a range of concentrations associated with a LOAEL endpoint. For these, we took the midrange value as an unbiased approximation of the LOAEL and estimated the NOAEL following the Canadian Council of Ministers of the Environment recommendation [41] (LOAEL $\div$ 5.6). Estimated prey fish $\mathrm{MeHg}$ values, endpoints, and information on the initial measurement matrix are listed in Table 2.

\section{RESULTS AND DISCUSSION}

\section{Summary of studies considered for survival endpoint}

Because common loon populations exhibit traits such as low annual productivity, delayed sexual maturity, long life expectancy, and suspected low adult mortality (http://bna.birds. cornell.edu/bna/species/313), even small declines in adult survival can have significant implications for population demographics [S17]. Data from mark-recapture programs do not provide compelling evidence for systematic changes in adult survival associated with $\mathrm{MeHg}$ exposure in Wisconsin and New
England [12,S18]. However, Mitro et al. [S18] indicate that small and likely significant changes $(<3 \%)$ are not yet detectable based on current data inventories and temporal records. Based on the 75th percentile of blood $\mathrm{Hg}$ concentrations reported by Mitro et al. [S18], the highest estimated unbounded adult survival NOAEL for dietary $\mathrm{MeHg}$ exposure in breeding adults is $\sim 0.6 \mu \mathrm{gg}^{-1}$ wet weight in prey fish (Table 2 and Fig. 1)

Adverse effects on the survival of captive loon chicks (up to $105 \mathrm{~d}$ posthatch) fed up to $1.2 \mu \mathrm{gg}^{-1}$ wet weight $\mathrm{MeHg}$ as $\mathrm{MeHgCl}$ have not been observed [S14]. However, the depuration of ingested $\mathrm{MeHg}$ into growing feathers may have protected loon chicks from more overt effects during the present study [S15]. Field studies assessing survival of juvenile loons are rare, but Meyer et al. [12] reported a negative association between chick survival beyond eight weeks of age and chick blood $\mathrm{Hg}$ concentrations in northern Wisconsin lakes, suggesting that in the wild, chick survival may be impaired when $\mathrm{Hg}$ exposure is elevated. Although other factors could not be ruled out, reduced survival of chicks associated with increased $\mathrm{MeHg}$ exposure is not inconsistent with observations in other species [42], but logistical and resource challenges continue to complicate assessment of juvenile survival in wild birds.

\section{Studies considered for growth and development endpoints}

The difficulties of keeping adult loons in captivity make assessment of adverse effects on growth or development difficult; therefore, most research has been conducted on wild adults. Evers et al. [S6] documented an increase in flight feather asymmetry in adults with very high levels of $\mathrm{Hg}$ in feathers (>40 $\mathrm{gg} \mathrm{g}^{-1}$ wet wt) and suggested that such developmental abnormalities may negatively affect individual fitness through increased energy expenditure. Barr [S1] reported that the mean weight of male loons from $\mathrm{Hg}$-polluted territories $(4.23 \mathrm{~kg}$ ) was lower than that in control territories $(4.62 \mathrm{~kg})$ and found one severely emaciated male loon on Ball Lake, Ontario, Canada between 1975 and 1976, although the weight of female loons did not show a similar pattern. Concentrations of $\mathrm{Hg}$ in yellow perch $(14.4 \pm 1.7$ to $16.6 \pm 3.1 \mathrm{~cm})$ ranged from 0.04 to $1.53 \mu \mathrm{gg}^{-1}$ wet weight in these territories, but water level fluctuations and associated turbidity may have also contributed to lower weights by reducing foraging success; therefore, attribution of lower body mass in male loons to $\mathrm{MeHg}$ exposure is not strongly supported. Emaciation is also encountered during necropsies of loons found dead or moribund, and some of these loons have high $\mathrm{Hg}$ burdens in liver and kidney tissues $[43,44]$, but wasting of body tissues will increase the $\mathrm{Hg}$ burden in the remaining carcass [44]

Available evidence is insufficient to determine what, if any, effects $\mathrm{MeHg}$ exposure may have on the growth and development of juvenile common loons at dietary $\mathrm{MeHg}$ concentrations up to $1.2 \mu \mathrm{gg}^{-1}$ wet weight [S14]. Stronger effects on body mass at hatch and asymptotic mass were related to the lake of origin of the collected eggs (see synopsis below). As discussed by Kenow et al. [S14], the lack of adverse effects on growth must be cautiously interpreted, because the results are applicable only to chicks up to $105 \mathrm{~d}$ of age and because of the potential protection provided by excretion of $\mathrm{MeHg}$ into feathers. Free-ranging loon chicks are known to have relatively high energetic demands [45], and the possibility exists that laboratory conditions designed to optimize chick survival may mask potential impacts on growth that are more likely to occur in the wild. For example, feeding studies of captive great egret chicks documented a reduction in weight gain resulting from reduced 
Table 2. Summary of studies on the common loon used in this review ${ }^{\mathrm{a}}$

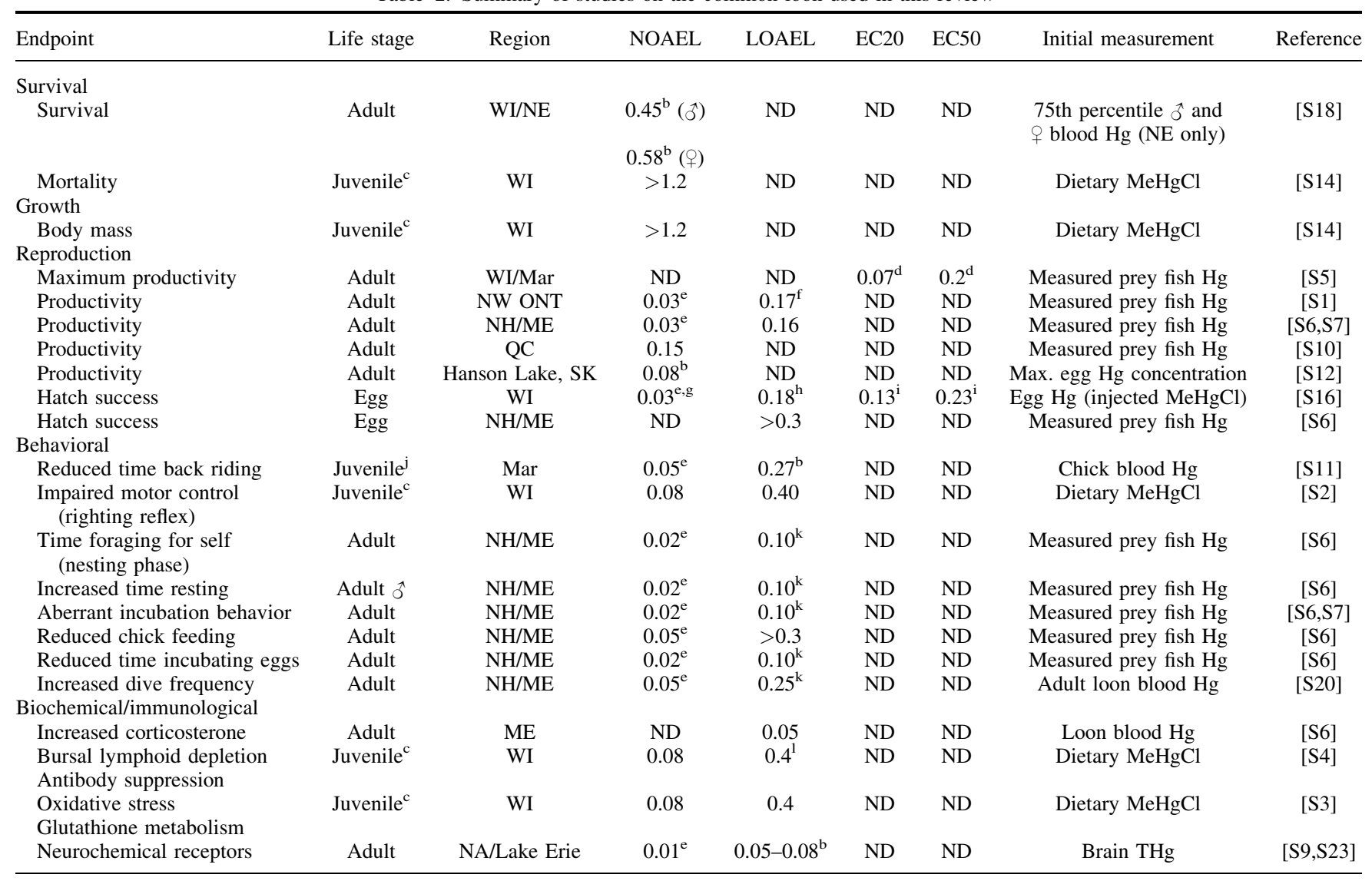

${ }^{\mathrm{a}}$ Included in the summary are the ecological endpoints assessed (endpoint), life stage of test subjects (life stage), geographic region within North America where the study was conducted or applicable (region), screening benchmarks derived from each study (adult no observed adverse effects level (NOAEL), low observed adverse effects level (LOAEL), effective concentration for 20\% (EC20) and effective concentration for 50\%; reported as concentration of Hg in prey fish, expressed as wet wt, $\mu \mathrm{g} \mathrm{g}^{-1}$ ), initial measurement matrix reported in each study with screening benchmarks (Initial measurement matrix; see Materials and Methods section), and source document (Reference) to identify the threshold.

${ }^{\mathrm{b}}$ Derivation following the steps outlined in the Materials and Methods section.

${ }^{\mathrm{c}}$ Chicks raised from egg to $105 \mathrm{~d}$ posthatch.

${ }^{\mathrm{d}}$ Calculated using the model presented by Burgess and Meyer [S5].

${ }^{\mathrm{e}}$ NOAEL calculated following the Canadian Council of Ministers of the Environment (CCME) [41].

${ }^{\mathrm{f}}$ Mean $\mathrm{Hg}$ content of fish from territories with minimal water level fluctuations.

${ }^{\mathrm{g}}$ Control eggs determined to contain $\sim 0.3 \mathrm{ppm} \mathrm{MeHg}$.

${ }^{\mathrm{h}}$ Determined to be significantly different from controls.

${ }^{\mathrm{i}}$ Estimated from model developed by Kenow et al. [S16].

${ }^{\mathrm{j}}$ Chicks $<12 \mathrm{~d}$ old.

${ }^{\mathrm{k}}$ Midrange value of prey fish $\mathrm{Hg}$ concentrations associated with the LOAEL.

${ }^{1}$ True LOAEL may be $<0.4$ based on magnitude of change in measured endpoints (immunoglobulin $\mathrm{G}$ titer).

$\mathrm{NE}=$ New England; $\mathrm{WI}=$ Wisconsin $; \mathrm{ME}=$ Maine; $\mathrm{QC}=$ Quebec; $\mathrm{SK}=$ Saskatchewan; Mar = Atlantic Canada; NW ONT = northwestern Ontario; $\mathrm{NA}=$ North America.

fish consumption [46], and lower weights were observed in wild egret chicks but at lower cumulative doses of $\mathrm{MeHg}$ than their captive counterparts (G.E. Williams, 1997, MSc thesis, University of Florida, Gainesville, FL, USA) [46], lending some indirect support for this hypothesis.

\section{Studies considered for reproductive endpoints}

In general, laboratory and field studies have demonstrated that, for many avian species, adverse effects on reproduction occur at dietary $\mathrm{MeHg}$ exposures one to two orders of magnitude below those that cause overt mortality or neurological symptoms [27]. The greater sensitivity of reproduction may be partially related to the many potential pathways by which $\mathrm{MeHg}$ can affect the reproductive process. $\mathrm{MeHg}$ may alter the mate selection and pairing behavior, incubation, and chick-rearing behavior of breeding adults [47,S6,S7], whereas deposition of $\mathrm{MeHg}$ into developing eggs may induce teratogenic effects in embryos [48], increase embryo mortality [49], reduce hatching success $[50, \mathrm{~S} 16]$, or affect the behavior of surviving offspring [3].

In an MeHg egg-injection experiment, Kenow et al. [S16] documented a dose-dependent decrease in hatching success and an increase in incubation time for common loon eggs and estimated the EC50 (median lethal concentration [LC50]) for hatching success to be $1.78 \mu \mathrm{gg}^{-1}$ wet weight. The lone reported death of a chick (at hatch) in the wild (Ball Lake [S1]) was associated with a whole-body residue of $2.44 \mu \mathrm{g} \mathrm{g}^{-1}$ wet weight. Using the carcass-to-egg conversion equation provided by Kenow et al. [S16], $\left(\log \operatorname{Egg}_{\mathrm{Hg}}=\left[\log \left[\operatorname{Carcass}_{\mathrm{Hg}}\right]-\right.\right.$ $\left.0.323] / 0.905, r^{2}=0.85\right)$ provides an estimate of $1.79 \mu \mathrm{g} \mathrm{g}^{-1}$ wet weight in the Ball Lake egg, which coincides with the experimentally determined EC50 [S16]. The EC20 (1.1 $\mu \mathrm{g} \mathrm{g}^{-1}$ 


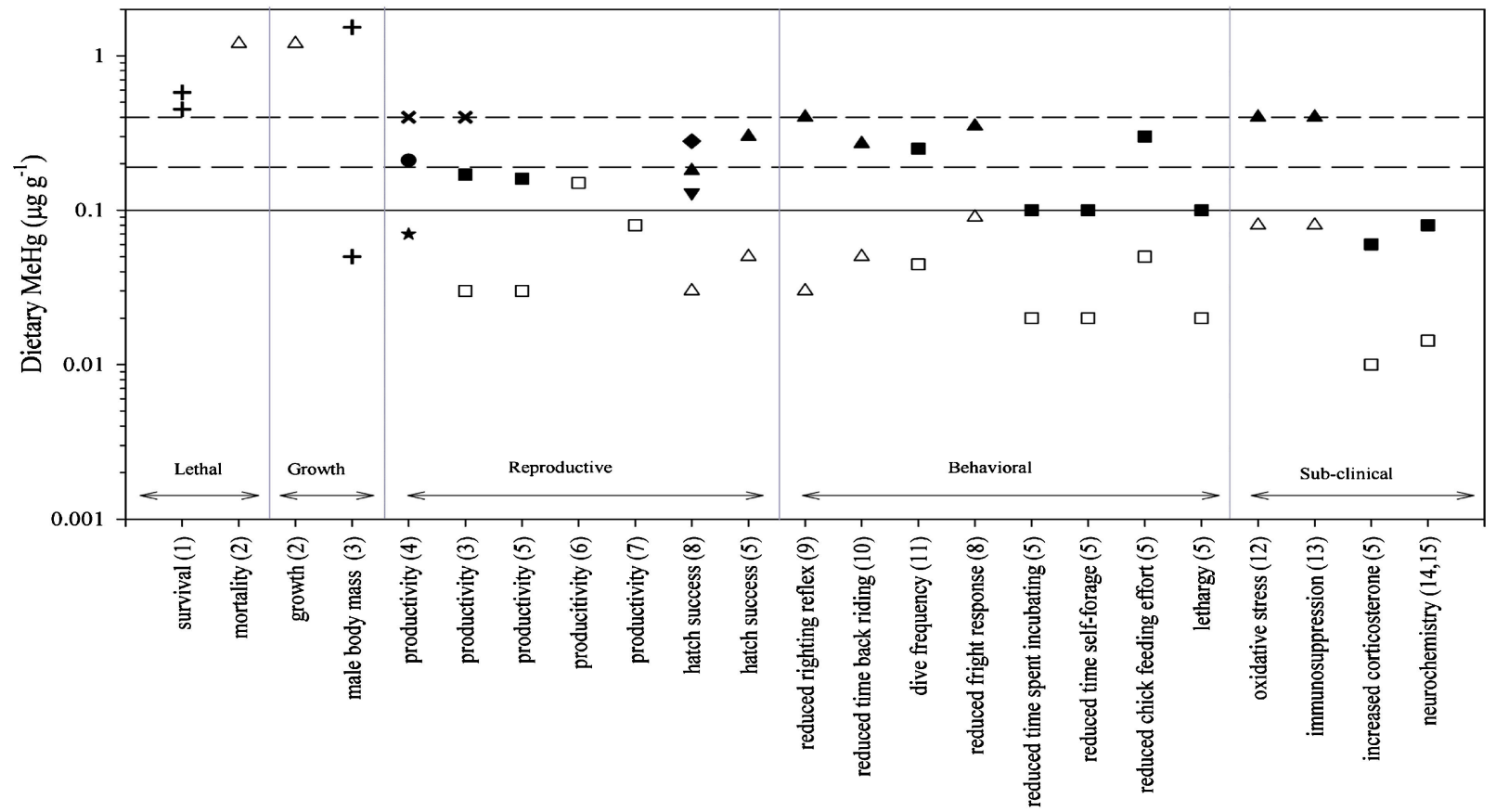

Fig. 1. Plot of relevant endpoints for deriving screening benchmarks for the common loon. Endpoints are sorted by category and displayed as follows: adult no observed adverse effects level (NOAEL; $\square$ ), adult low observed adverse effects level (LOAEL; $\mathbf{\square}$ ), adult EC20 ( $\star$ ), adult EC50 (○), juvenile NOAEL ( $\Delta$ ), juvenile LOAEL ( $\mathbf{\Delta})$, juvenile effective concentration for 20\% (EC20; $\boldsymbol{\nabla})$ and juvenile effective concentration for 50\% (EC50; $\bullet$ ), $\boldsymbol{+}$ Represents the estimated upper and lower ranges of dietary exposure associated with relevant endpoints, and $\mathbf{X}$ represents the effective concentration for 100\% (EC100). The solid line indicates the proposed behavioral benchmark $\left(0.1 \mu \mathrm{g} \mathrm{g}^{-1}\right)$, the line with longer dashes represents the reproductive impairment benchmark $\left(0.18 \mu \mathrm{g} \mathrm{g}{ }^{-1}\right)$, and the line with shorter dashes represents the reproductive failure benchmark $\left(0.4 \mu \mathrm{g} \mathrm{g}^{-1}\right)$. Supplemental References for selected endpoints are as follows: 1, [S18]; 2 , [S14]; 3, [S1]; 4, [S5]; 5, [S6]; 6, [S10]; 7, [S12]; 8, [S16]; 9, [S2]; 10, [S11]; 11, [S20]; 12, [S3]; 13, [S4]; 14, [S9]; and 15, [S23].

wet wt) and EC50 correspond to an estimated concentration of 0.13 and $0.23 \mu \mathrm{g} \mathrm{g}^{-1}$ wet weight, respectively, in maternal diets (Table 2 and Fig. 1). Although it has not been directly demonstrated with common loon eggs, it appears that, in general, when $\mathrm{MeHgCl}$ is injected into eggs, it is more toxic than maternally deposited $\mathrm{MeHg}$ [49]. However, the EC20 and EC50 from the egg injection study bracket the threshold level of $1.3 \mu \mathrm{g} \mathrm{g}^{-1}$ wet weight indicative of loons from territories where prey fish $\mathrm{Hg}$ typically exceeds $0.3 \mu \mathrm{gg}^{-1}$ wet weight [S1,S8].

Productivity is arguably the most ecologically relevant reproductive endpoint because overall productivity integrates potential adverse effects of $\mathrm{MeHg}$ on adult behavior, egg production and incubation, embryonic development and hatching success, posthatch parental care, and chick survival. However, productivity may also be affected by prey availability [31,S13] and anthropogenic disturbances such as water level regulation [S1] and recreational activity [51]. These confounding effects undoubtedly vary spatially and temporally and may not be readily separable from effects related to $\mathrm{MeHg}$ exposure. For example, although Merrill et al. [S13] found that loon chick survival was unrelated to lake $\mathrm{pH}$ and cumulative $\mathrm{Hg}$ exposure in Wisconsin lakes, nearly $75 \%$ of the lakes studied were classified as "seepage" (i.e., no inlets or outlets; see Meyer et al. [12]). Such lakes can have low fish diversity and abundance because of barriers to fish migration and frequent wintertime anoxia [52]. In addition, heightened sensitivity to acidrelated reductions in invertebrate and fish abundance [53] may also affect prey availability [S13].

Despite the potential for confounding stressors to complicate the assessment of $\mathrm{MeHg}$ exposure on productivity, studies published to date share a number of consistencies. On highly contaminated Ball Lake, breeding adult female loons laid fewer eggs, and productivity and hatching success declined by 82 and $42 \%$, respectively, relative to upstream reference territories [S1]. These reductions in reproductive success occurred in territories unaffected by water level fluctuations but accessible to fish with high $\mathrm{MeHg}$ concentrations (mean $0.17 \pm 0.09 \mu \mathrm{gg}^{-1}$, range $0.05-0.35 \mu \mathrm{gg}^{-1}$ wet wt [S1]). Reproduction ceased completely in territories where concentrations of $\mathrm{MeHg}$ in prey fish were $>0.4 \mu \mathrm{g} \mathrm{g}^{-1}$ wet weight, although these territories were also affected by water level manipulation and high turbidity [S1]. Evers et al. [S6,S7] documented a $13 \%$ reduction in egg laying and a $30 \%$ reduction in hatching success on lakes in the northeastern United States where prey fish $\mathrm{Hg}$ was $>0.3 \mu \mathrm{g} \mathrm{g}^{-1}$ wet weight. Productivity in these territories was reduced by $40 \%$ where fish $\mathrm{Hg}$ levels were between 0.15 and $0.3 \mu \mathrm{g} \mathrm{g}^{-1}$ wet weight, prompting Evers et al. [S7] to suggest a threshold level (LOAEL) of $0.16 \mu \mathrm{g} \mathrm{g}^{-1}$ wet weight in prey fish for significant impacts on loon productivity. Burgess et al. [S19] observed a reduced tendency for breeding adult loons to nest, accompanied by a decline in productivity as blood Hg levels increased in Kejimkujik National Park, Nova Scotia, Canada. A recent reanalysis of data from Atlantic Canada and Wisconsin indicated that reductions in maximum productivity are likely related to $\mathrm{MeHg}$ exposure, and a $50 \%$ reduction is predicted to occur at prey fish $\mathrm{MeHg}$ levels of $\sim 0.21 \mu \mathrm{gg}^{-1}$ wet weight, and successful reproduction is predicted to cease completely at prey fish $\mathrm{MeHg}$ levels of $>0.4 \mu \mathrm{gg}^{-1}$ wet weight [S5].

Unlike the above-mentioned studies, the study of Champoux et al. [S10] did not find strong evidence that loon productivity in selected lakes was affected by $\mathrm{MeHg}$ levels in prey fish in Quebec. Although somewhat contradictory at first glance, the majority of lakes examined in this study had mean prey fish $\mathrm{MeHg}$ levels of $<0.15 \mu \mathrm{gg}^{-1}$ wet weight, and extraneous 
stressors such as human disturbances were not explicitly controlled. Impacts on productivity might have been less pronounced compared to those in other regions where $\mathrm{MeHg}$ levels in prey fish more frequently exceed $0.15 \mu \mathrm{g} \mathrm{g}^{-1}$ wet weight. Similarly, Fox et al. [S12] were unable to find evidence of contaminant-related declines in productivity in loon territories on Hanson Lake, Saskatchewan, Canada. However, $\mathrm{MeHg}$ exposure in loons on Hanson Lake was low; based on the maximum recorded egg $\mathrm{Hg}$, the estimated maximum $\mathrm{MeHg}$ in prey fish was $0.08 \mu \mathrm{gg}^{-1}$ wet weight (Table 2 and Fig. 1). Although all confounding factors that influence productivity cannot be completely eliminated, the consistency between studies in differing regions of North America [S1,S5S7,S10,S12] provides strong evidence that loon productivity is sensitive to $\mathrm{MeHg}$ exposure and that moderate concentrations of $\mathrm{MeHg}$ in prey fish (e.g., $0.1-0.2 \mu \mathrm{g} \mathrm{g}^{-1}$ wet wt) may significantly reduce productivity (i.e., $>40 \%$ ).

\section{Summary of studies considered for behavioral endpoints}

The potent neurotoxicity of $\mathrm{MeHg}$ is well known, and at sufficient concentrations ( $>5 \mu \mathrm{gg}^{-1}$ wet weight) $\mathrm{MeHg}$ can elicit overt neurological symptoms, including ataxia and gross motor impairment in birds [26,27]. However, for birds exposed to lower $\mathrm{MeHg}$ concentrations, behavioral abnormalities may be considerably more subtle and thus difficult to link to apical outcomes of survival or reproduction [10].

Increased $\mathrm{Hg}$ exposure has been correlated with an increased frequency of lethargic behaviors in breeding adult loons. In breeding territories where $\mathrm{Hg}$ concentrations in prey fish are between 0.05 and $0.15 \mu \mathrm{gg}^{-1}$ wet weight, adults spent more time preening and resting and less time foraging for themselves and significantly reduced amounts of time spent incubating eggs $(\sim 10 \%)$ compared with breeding adults on territories where prey fish $\mathrm{Hg}$ concentrations were $<0.05 \mu \mathrm{gg}^{-1}$ wet weight [S6,S7]. In territories where prey fish $\mathrm{Hg}$ concentrations exceeded $0.3 \mu \mathrm{g} \mathrm{g}^{-1}$ wet weight, food provisioning for chicks was reduced by $42 \%$ relative to that in territories where prey fish $\mathrm{Hg}$ concentrations were $<0.05 \mu \mathrm{g} \mathrm{g}^{-1}$ wet weight [S6], and dive frequencies of adults were observed to increase substantially [S20], although a plausible link to $\mathrm{MeHg}$ exposure remains equivocal [S21] (Table 2 and Fig. 1).

Field studies have documented subtle behavioral alterations in loon chicks at different stages of development. Loon chicks $<12$ d-old spent less time back-riding, potentially increasing unnecessary energy expenditures and increasing vulnerability to predation and exposure [S11]. The concentration of $\mathrm{MeHg}$ in prey associated with a complete cessation in back riding was estimated to be $\sim 0.3 \mu \mathrm{gg}^{-1}$ wet weight (Table 2 and Fig. 1). Counard [S22] observed a negative relationship between the frequency of wing flaps and diving, and a corresponding increase in swimming, peering, and begging as blood $\mathrm{Hg}$ concentrations increased in $>40$-d-old chicks. These behaviors were not observed by Kenow et al. [S2] in their captive chick study, but they did report impaired motor coordination (measured by righting reflex) in $>37$-d-old chicks fed $0.4 \mu \mathrm{g} \mathrm{g}^{-1}$ wet weight $\mathrm{MeHgCl}$.

The behavioral effects discussed above appear to manifest when prey $\mathrm{MeHg}$ concentrations are between 0.05 and $0.4 \mu \mathrm{gg}^{-1}$ wet weight (Table 2 and Fig. 1) and generally suggest a shift toward less energetic behaviors in adults [S6,S7], but the response of chicks is often more ambiguous [S2,S11,S16,S22]. Overall, observed behavioral aberrations are comparable to those associated with $\mathrm{MeHg}$ exposure in other piscivorous species [5]. Some of the behavioral impairments exhibited by adult loons may adversely affect productivity. A reduction in time spent incubating eggs will increase the risk of egg loss to nest predation and chilling [S7] and may be linked to increased incidences of embryo malposition resulting from improper turning of the eggs during incubation [54]. Reductions in chick feeding effort may directly impair the growth and survival of loon chicks, insofar as underprovisioning is linked to failure of chicks to fledge or to abandonment [55]. Bridging the gap between observed behavioral impairments and changes in individual fitness, survival, or reproductive success remains a worthwhile albeit difficult approach for assessing the impacts of $\mathrm{MeHg}$ exposure in loons and other wildlife.

\section{Summary of studies considered for subclinical endpoints}

In recent years, the volume of data detailing mechanistic responses to $\mathrm{MeHg}$ exposure in wildlife at the molecular, biochemical, and cellular levels has expanded considerably [56]. Dietary exposure trials with mallard ducks (Anas platyrhynchos) [8] developed a suite of biochemical and physiological endpoints that responded to $\mathrm{MeHg}$ exposure in the laboratory, and these have been validated in wild birds from various locations [57-59]. Some of these biochemical endpoints have been observed in common loons. At dietary exposure concentrations of 0.4 and $1.2 \mu \mathrm{gg}^{-1}$ wet weight, evidence of oxidative stress and altered glutathione metabolism was observed in brain tissues of captive loon chicks [S3]. At dietary exposures of $0.4 \mu \mathrm{gg}^{-1}$ wet weight, atrophy and lymphoid depletion of the thymus and bursa and a reduction in T-cellmediated immune response $(\sim 40 \%)$ were observed in captive loon chicks, and the declines in antibody titer (immunoglobulin $\mathrm{G})$ in the $0.08 \mu \mathrm{gg}^{-1}$ wet weight exposure group were comparable to those in the $0.4 \mu \mathrm{gg}^{-1}$ wet weight exposure group (54 vs 58\%), although this difference was deemed not significant [S4] (Table 2 and Fig. 1).

Comparable data for adult loons is not available primarily because of the difficulty in acquiring samples for analysis. However, significant elevations in blood corticosterone concentrations in wild adult loons were observed in loon territories where prey fish $\mathrm{Hg}$ concentrations were $>0.05 \mu \mathrm{gg}^{-1}$ wet weight [S6], and significant correlations were found between brain $\mathrm{Hg}$ concentrations (in which $\mathrm{Hg}$ concentrations ranged from $0.2-68 \mu \mathrm{g} \mathrm{g}^{-1}$ dry $\mathrm{wt}$ ) and the densities of muscarinic cholinergic receptors and $N$-methyl- $D$-aspartic acid receptors in wild loons collected opportunistically across Canada [S9]. Changes in these neurochemical receptor densities are known to elicit deleterious effects on motor function, memory, and learning in mammals $[60,61]$ but have been rarely studied in birds. Based on the data presented by Scheuhammer et al. and Hamilton et al. [S9,S23], a brain Hg concentration of approximately $3 \mu \mathrm{gg}^{-1}$ dry weight $\left(\sim 0.75 \mu \mathrm{g} \mathrm{g}^{-1}\right.$ wet wt, assuming $75 \%$ moisture content) may represent a threshold below which significant changes in neurochemical receptor densities do not occur in loons [S23]. This corresponds to an estimated minimum dietary $\mathrm{MeHg}$ concentration of $0.05-0.08 \mu \mathrm{g} \mathrm{g}^{-1}$ wet weight (Table 2 and Fig. 1). Although potentially biased by the use of a model constructed for juvenile loons (see Materials and Methods), this level of $\mathrm{MeHg}$ exposure is comparable to dietary exposure concentrations associated with similar changes observed in brains of mink (Mustela vision; $\left(0.1 \mathrm{\mu g} \mathrm{g}^{-1}\right.$ wet wt [62]).

Although these biomarkers are demonstrably sensitive to low-level $\mathrm{MeHg}$ exposure, linking the measured response to individual or population-level effects remains difficult. For example, loon chicks fed 0.4 and $1.2 \mu \mathrm{gg}^{-1}$ wet weight 
$\mathrm{MeHgCl}$ were less likely to right themselves when placed on their backs [S2], and evidence of oxidative stress and altered glutathione metabolism was present in brain tissue [S3]. In great egret chicks fed $0.5 \mu \mathrm{gg}^{-1}$ wet weight $\mathrm{MeHg}$, behavioral aberrations were observed [5], but evidence of oxidative stress in brain tissue was not apparent until dietary exposure reached $5 \mu \mathrm{gg}^{-1}$ wet weight [63] and chicks displayed significant overt neurological dysfunction [6]. Immune system suppression related to $\mathrm{MeHg}$ exposure appears to be generally universal in avian species tested to date $[6,58]$, and high $\mathrm{MeHg}$ exposure has previously been linked to chronic disease occurrence in freeranging aquatic birds [44,64]. The reduced T-cell-mediated immunity observed in loon chicks ( $\sim 40 \%$ reduction), although not statistically significant, may nonetheless be indicative of significant immune system suppression [S4] that may not only impair the ability of birds to resist infectious diseases or parasites but also may impair overall population fitness, leading to population-level impacts [37]. Although these more recent studies are providing sensitive tools and approaches with which to evaluate $\mathrm{MeHg}$ exposure in birds, their integration into ecological risk assessment approaches remains limited at present.

\section{Synopsis, remaining uncertainties, and screening benchmarks}

We propose, based on our review of the literature, three screening benchmarks based on three categories of relevant endpoints using a weight-of-evidence approach (Table 3). However, we refrain from proposing benchmark thresholds for loon chicks or for lethal effects in both chicks and adult loons because of the residual uncertainty surrounding the assessment of long-term survival.

For loon chicks, several factors contribute to greater uncertainty in the development of appropriate screening benchmarks. One aspect is related to the variable exposure profile observed for common loon chicks [S15] and chicks of other piscivorous species [65]. The highest $\mathrm{MeHg}$ exposures occur immediately after hatching (from maternal transfer of $\mathrm{MeHg}$ ) and again when feather growth ceases and a key depuration pathway is no longer available, suggesting that risk may be highest during these time periods [65]. Because the captive feeding studies with loon chicks were terminated at 15 weeks of age and blood $\mathrm{Hg}$ levels were on an upward trajectory at that time, negative effects on chicks beyond this time frame are unknown, but are potentially significant [S14]. The presence of adverse behavioral effects in loon chicks $<12$ d-old [S11] and $>37$ d-old [S2,S22] is not inconsistent with the hypothesized pattern of risk, but more data are required to help reduce uncertainty in deriving a screening benchmark for loon chicks.

A second aspect related to uncertainty surrounding loon chicks is that in ovo exposure appears to be more important than dietary exposure to the susceptibility of juveniles. This is highlighted by the strong and consistent lake-source effect observed by Kenow et al. [S2-4,S14,S16] in their series of captive loon chick experiments. Chicks hatched from eggs collected on low-pH lakes, where exposure to $\mathrm{Hg}$ is known to be higher compared with neutral-pH lakes [11,12] weighed $3.8 \%$ less at hatch, had $7 \%$ lower asymptotic mass [S14], were less responsive to parental calls [S2] and to frightening stimuli [S16], had more severe physiological effects [S3], and had more depressed immune function [S4] compared with chicks hatched from eggs on neutral-pH lakes.

We did not propose a benchmark dose for survival because survival is difficult to assess outside of acute lethality. The lack of acute lethality in captive fed loon chicks or obvious impairment of adult survival inferred from field studies is perhaps not overly surprising, because the lethal dietary threshold for nonmarine avian species reported by Shore et al. [27] is $>6 \mu \mathrm{g} \mathrm{g}^{-1}$ (range, $10-40 \mu \mathrm{g} \mathrm{g}^{-1} ; 11$ species), and this far exceeds concentrations of $\mathrm{Hg}$ provided to loon chicks in captivity [S14] or preferred prey fish species typically consumed by adult loons in North America [25,66,67]. However, evidence suggests that some recaptured wild adult loons in northeastern North America exhibit annual increases in feather $\mathrm{Hg}\left(\sim 5-10 \%\right.$ year $\left.^{-1}\right)$ [S7]. This may indicate either an increase in $\mathrm{Hg}$ exposure or perhaps incomplete depuration on wintering grounds [S7]. Mortality of adult loons is rarely reported on summer breeding grounds and likely is more common during migration and over winter, making assessment of survival in the wild difficult without substantial data inventories [S18]. Necropsies of dead or moribund loons $[43,44]$ have frequently documented high $\mathrm{Hg}$ burdens in various tissues (especially in emaciated individuals), but causes of death are often related to lead toxicity, trauma, or respiratory infection and aspergillosis [68]. Although the possibility exists that $\mathrm{MeHg}$ exposure contributes to some extent to loon mortalities, a lack of compelling evidence and the paucity of data pertaining to survival rates of juvenile and nonbreeding loons hinders assessment of $\mathrm{Hg}$ impacts on long-term survival and population dynamics.

\section{Proposed benchmark dietary concentrations}

A screening benchmark of $0.1 \mu \mathrm{g} \mathrm{g}^{-1}$ wet weight is proposed to be associated with alterations to normal adult loon behaviors (Table 3 and Fig. 1). The level of uncertainty surrounding this benchmark concentration is relatively high because this essentially represents the midpoint of a range of values $(0.05-$ $0.15 \mu \mathrm{g} \mathrm{g}^{-1}$ wet wt) over which behavioral aberrations have been observed. That this midrange value closely corresponds to an estimated dietary level at which neurochemical changes are observed in loon brain tissue (Table 2 and Fig. 1) may simply be coincidental but certainly merits further study. Importantly, the degree to which these adult behavioral changes will affect adult or chick survival in the wild or population dynamics is presently

Table 3. Summary of proposed screening benchmarks for common loon exposure to $\mathrm{MeHg}^{\mathrm{a}}$

\begin{tabular}{lcc}
\hline Category & $\begin{array}{c}\text { Proposed screening } \\
\text { benchmark threshold } \\
\left(\mu \mathrm{g} \mathrm{g}^{-1}\right) \text { wet weight }\end{array}$ & Endpoints considered \\
\hline $\begin{array}{l}\text { Adult behavioral abnormalities } \\
\text { Significant reproductive impairment }\end{array}$ & 0.1 & $\begin{array}{c}\text { Midpoint of range for adverse adult behavior LOAELs } \\
\text { Geometric mean of productivity LOAEL } \\
\text { and EC50, hatch success EC50 } \\
\text { Peproductive failure }\end{array}$ \\
\hline
\end{tabular}

${ }^{\text {a }}$ Screening benchmarks are expressed as $\mathrm{Hg}$ concentrations in prey fish $\left(\mu \mathrm{gg}^{-1}\right.$ wet wt).

LOAELs $=$ low observed adverse effects level; EC50 = effective concentration for $50 \%$. 
unknown; therefore, the suitability of this benchmark for ecological risk assessment remains limited.

The remaining screening benchmarks $\left(0.18 \mu \mathrm{gg}^{-1}\right.$ and $0.4 \mu \mathrm{g} \mathrm{g}^{-1}$, wet wt) are proposed to be indicative of significant reproductive impairment and reproductive failure, respectively, in breeding adult common loons. These benchmarks for the common loon bracket the dietary value proposed by Shore et al. [27] to be indicative of reproductive impairment in nonmarine birds $\left(0.25 \mu \mathrm{g} \mathrm{g}^{-1}\right.$; one-fifth of the geometric mean of LOAEL for seven species). We consider these screening benchmarks to have a lower level of uncertainty than the behavioral benchmark, because strong associations with significant (40-50\%) declines in productivity have been documented in Ontario, Wisconsin, Atlantic Canada, and the northeastern United States (Table 3 and Fig. 1). The consistency of these effects across regions and the direct assessment of loons in a natural environment strongly suggest that these screening benchmarks are reasonably well defined. Moreover, although demographic models suggest a low sensitivity of population stability to changes in productivity [S17], declines in productivity on the order of $40 \%$ have been associated with negative population growth rates in Maine from 1982 to 1999 [S6], and a complete failure of reproduction will obviously impair population stability. These benchmarks are clearly relevant to the assessment of ecological risk to the common loon based on dietary exposure to $\mathrm{MeHg}$.

\section{CONCLUSIONS}

The common loon is clearly vulnerable to dietary $\mathrm{MeHg}$ exposure in the range of 0.1 to $0.4 \mu \mathrm{g} \mathrm{g}^{-1}$ wet weight. These concentrations are found in preferred prey fish species within their breeding lakes across North America. The three screening benchmarks developed here use directly applicable data for common loons and will allow for a tiered assessment of risk in ecological risk assessment. Continued refinement and enhancement of population models and further understanding of linkages between highly sensitive biochemical endpoints and individual- or population-level responses will further enhance the ability to define adverse effect thresholds related to $\mathrm{MeHg}$ in the common loon as well as other species of avian piscivores.

\section{SUPPLEMENTAL DATA}

\section{Supplemental References S1-S23. (41 KB DOC).}

Acknowledgement-The present study is the result of a workshop held at the 31st Annual Meeting of SETAC in Portland, Oregon. The authors thank M. Meyer (Wisconsin Department of Natural Resources), K. Kenow (U.S. Geological Survey), K.Williams (Biodiversity Research Institute), and R. Shore (Center for Ecology and Hydrology, United Kingdom) for thoughtful discussion and kindly sharing advance copies of manuscripts. The workshop was funded by Environment Canada. Comments from two anonymous reviewers improved the quality of the original manuscript.

\section{REFERENCES}

1. Scheuhammer AM, Sandheinrich MB. 2008. Recent advances in the toxicology of methylmercury in wildlife. Ecotoxicology 17:67-68.

2. Fimreite N. 1970. Effects of methyl mercury treated feed on mortality and growth of leghorn cockerels. Can J Anim Sci 50:387.

3. Heinz GH. 1979. Methylmercury: Reproductive and behavioral effects on three generations of mallard ducks. $J$ Wildl Manag 43:394-401.

4. Fimreite N. 1974. Mercury contamination of aquatic birds in northwestern Ontario. J Wildl Manag 38:120-131.

5. Bouton SN, Frederick PC, Spalding MG, McGill H. 1999. Effects of chronic, low concentrations of dietary methylmercury on the behavior of juvenile great egrets. Environ Toxicol Chem 18:1934-1939.
6. Spalding MG, Frederick PC, McGill HC, Bouton SN, Richey LJ, Schumacher IM, Blackmore CGM, Harrison J. 2000. Histologic, neurologic, and immunologic effects of methylmercury in captive great egrets. J Wildl Dis 36:423-435.

7. Rutkiewicz J, Nam D, Cooley T, Neumann K, Padilla IB, Route W, Strom S, Basu N. 2011. Mercury exposure and neurochemical impacts in bald eagles across several Great Lakes states. Ecotoxicology 20:16691676.

8. Hoffman DJ, Heinz GH. 1998. Effects of mercury and selenium on glutathione metabolism and oxidative stress in mallard ducks. Environ Toxicol Chem 17:161-166.

9. Evers DC, Han Y, Driscoll CT, Kamman NC, Goodale MW, Lambert KF, Holsen TM, Chen CY, Clair TA, Butler T. 2007. Biological mercury hotspots in the northeastern United States and southeastern Canada. BioScience 57:29-43.

10. Scheuhammer AM, Meyer MW, Sandheinrich MB, Murray MW. 2007. Effects of environmental methylmercury on the health of wild birds, mammals, and fish. Ambio 36:12-19.

11. Meyer MW, Evers DC, Daulton T, Braselton WE. 1995. Common loons (Gavia immer) nesting on low $\mathrm{pH}$ lakes in northern Wisconsin have elevated blood mercury content. Water Air Soil Pollut 80:871-880.

12. Meyer MW, Evers DC, Hartigan JJ, Rasmussen PS. 1998. Patterns of common loon (Gavia immer) mercury exposure, reproduction, and survival in Wisconsin, USA. Environ Toxicol Chem 17:184-190.

13. Meyer MW, Rasmussen PW, Watras CJ, Fevold BM, Kenow KP. 2011. $\mathrm{Bi}$-phasic trends in mercury concentrations in blood of Wisconsin common loons during 1992-2010. Ecotoxicology 20:1659-1668.

14. Evers DC, Kaplan JD, Meyer MW, Reaman PS, Braselton WE, Major A, Burgess N, Scheuhammer AM. 1998. Geographic trend in mercury measured in common loon feathers and blood. Environ Toxicol Chem 17:173-183.

15. Evers DC, Williams KA, Meyer MW, Scheuhammer AM, Schoch N, Gilbert AT, Siegel L, Taylor RJ, Poppenga R, Perkins CR. 2011. Spatial gradients of methylmercury for breeding common loons in the Laurentian Great Lakes region. Ecotoxicology 20:1609-1625.

16. Burgess NM, Evers DC, Kaplan JD. 2005. Mercury and other contaminants in common loons breeding in Atlantic Canada. Ecotoxicology 14:241-252.

17. Scheuhammer AM, Atchison CM, Wong AHK, Evers DC. 1998 Mercury exposure in breeding common loons (Gavia immer) in central Ontario, Canada. Environ Toxicol Chem 17:191-196.

18. Scheuhammer AM, Blancher PJ. 1994. Potential risk to common loons (Gavia immer) from methylmercury exposure in acidified lakes. Hydrobiol 279/280:445-455.

19. Barr JF. 1996. Aspects of common loon (Gavia immer) feeding biology on its breeding ground. Hydrobiology 321:119-144.

20. Evers DC. 2006. Loons as biosentinels of aquatic integrity. Environ Bioindicators 1:18-21.

21. Nacci D, Pelletier M, Lake J, Bennett R, Nichols J, Haebler R, Grear J, Kuhn A, Copeland J, Nicholson M, Walters S, Munns WR. 2005. An approach to predict risks to wildlife populations from mercury and other stressors. Ecotoxicology 14:283-293.

22. Morrison H. 2011. The Canadian Clean Air Regulatory Agenda Mercury Science Program. Ecotoxicology 20:1512-1519.

23. Monson BA. 2009. Trend reversal of mercury concentrations in piscivorous fish from Minnesota lakes: 1982-2006. Environ Sci Technol 43:1750-1755

24. Bhavsar SP, Gewurtz SB, McGoldrick DJ, Keir MJ, Backus SM. 2010. Changes in mercury levels in Great Lakes fish between 1970s and 2007. Environ Sci Technol 44:3273-3279.

25. Wyn B, Kidd KA, Burgess NM, Curry RA, Munkittrick KR. 2010 Increasing mercury in yellow perch at a hotspot in Atlantic Canada, Kejimkujik National Park. Environ Sci Technol 44:9176-9181.

26. Wolfe MF, Schwarzbach S, Sulaiman RA. 1998. Effects of mercury on wildlife: A comprehensive review. Environ Toxicol Chem 17: 146-160.

27. Shore RF, Pereira G, Walker LA, Thompson DR. 2011. Mercury in nonmarine birds and mammals. In Beyer WN, Meador JP, eds, Environmental Contaminants in Wildlife: Interpreting Tissue Concentrations, 2nd ed. CRC, Boca Raton, FL, USA, pp 609-624.

28. Suter GW. 2007. Ecological Risk Assessment. CRC, Boca Raton, FL, USA.

29. Sample BE, Opresko DM, Suter GW. 1996. Toxicological benchmarks for wildlife: 1996 Revision. ES/ER/TM-86/R3. Health Sciences Research Division, Oak Ridge, TN, USA

30. Allard P, Fairbrother A, Hope BK, Hull RN, Johnson MS, Kapustka L, Mann G, McDonald B, Sample BE. 2010. Recommendations for the 
development and application of wildlife toxicity reference values. Integr Environ Assess Manag 6:28-37.

31. Alvo R, Hussell DJT, Berrill M. 1988. The breeding success of common loons (Gavia immer) in relation to alkalinity and other lake characteristics in Ontario. Can J Zool 66:746-752.

32. Parker KE. 1988. Common loon reproduction and chick feeding on acidified lakes in the Adirondack Park, New York. Can J Zool 66: 804-810.

33. Hunt GL, Hunt MW. 1976. Gull chick survival: the significance of growth rates, timing of breeding and territory size. Ecology 57:62-75.

34. Ricklefs RE, Bloom G. 1977. Components of avian breeding productivity. Auk 94:86-96.

35. Lewis SJ, Malecki RA. 1984. Effects of egg oiling on larid productivity and population dynamics. Auk 101:584-592.

36. Kramer VJ, Etterson MA, Hecker M, Murphy CA, Roesijadi G, Spade DJ, Spromberg JA, Wang M, Ankley GT. 2011. Adverse outcome pathways and ecological risk assessment: bridging to population-level effects. Environ Toxicol Chem 30:64-76.

37. Møller AP, Cassey P. 2004. On the relationship between T-cell mediated immunity in bird species and the establishment success of introduced populations. J Anim Ecol 73:1035-1042.

38. Hammerschmidt CR, Wiener JG, Frazier BE, Rada RG. 1999. Methylmercury content of eggs in yellow perch related to maternal exposure in four Wisconsin lakes. Environ Sci Technol 33:999-1003.

39. Office of Pesticide Programs. 1982. Pesticide assessment guidelines. Subdivision E, Hazard evaluation: Wildlife and Aquatic Organisms. EPA 540/9-82/024. U.S. Environmental Protection Agency, Washington DC

40. Suter GW, Cornaby BW, Hadden CT, Hull RN, Stack M, Zafran FA. 1995. An approach for balancing health and ecological risks at hazardous-waste sites. Risk Anal 15:221-231.

41. Canadian Council of Ministers of the Environment. 1998. A protocol for the derivation of Canadian tissue residue guidelines for the protection of wildlife that consume aquatic biota. Winnipeg, Manitoba, Canada

42. Sepulveda MS, Williams GE, Frederick PC, Spalding MG. 1999. Effects of mercury on health and first-year survival of free-ranging great egrets (Ardea albus) from southern Florida. Arch Environ Contam Toxicol 37:369-376.

43. Frank R, Lumsden H, Barr JF, Braun HE. 1983. Residues of organochlorine insecticides, industrial chemicals, and mercury in eggs and in tissues taken from healthy and emaciated common loons, Ontario, Canada, 1968-1980. Arch Environ Contam Toxicol 12:641653.

44. Daoust PY, Conboy G, McBurney S, Burgess N. 1998. Interactive mortality factors in common loons from Maritime Canada. J Wildl Dis 34:524-531.

45. Fournier F, Karasov WH, Meyer MW, Kenow KP, Hohman WH. 2002. Daily energy expenditures of free-ranging common loon (Gavia immer) chicks. Auk 119:1121-1126.

46. Spalding MG, Frederick PC, McGill HC, Bouton SN, McDowell LR. 2000. Methylmercury accumulation in tissues and its effects on growth and appetite in captive great egrets. J Wildl Dis 36:411-422.

47. Frederick P, Jayasena N. 2011. Altered pairing behaviour and reproductive success in white ibises exposed to environmentally relevant concentrations of methylmercury. Proc R Soc B Biol Sci 278:1851-1857.

48. Hoffman DJ, Moore JM. 1979. Teratogenic effects of external egg applications of methyl mercury in the mallard, Anas platyrhynchos. Teratology 20:453-461.

49. Heinz GH, Hoffman DJ, Klimstra JD, Stebbins KR, Kondrad SL, Erwin CA. 2009. Species differences in the sensitivity of avian embryos to methylmercury. Arch Environ Contam Toxicol 56:129-138.

50. Heinz G. 1974. Effects of low dietary levels of methylmercury on mallard reproduction. Bull Environ Contam Toxicol 11:386-392.
51. Heimberger M, Euler D, Barr JF. 1983. The impact of cottage development on common loon reproductive success in central Ontario. Wilson Bull 95:431-439.

52. Tonn WM, Magnuson JJ. 1982. Patterns in the species composition and richness of fish assemblages in northern Wisconsin lakes. Ecology 63:1149-1166.

53. Schindler DW. 1988. Effects of acid-rain on freshwater ecosystems. Science 239:149-157.

54. Herring G, Ackerman JT, Eagles-Smith CA. 2010. Embryo malposition as a potential mechanism for mercury-induced hatching failure in bird eggs. Environ Toxicol Chem 29:1788-1794.

55. Gingras BA, Paszkowski CA. 1999. Breeding patterns of common loons on lakes with three different fish assemblages in north-central Alberta. Can J Zool 77:600-609.

56. Wolfe MF, Atkeson T, Bowerman W, Burger J, Evers DC, Murray MW 2005. Wildlife indicators. In Harris RC, Krabbenhoft DP, Mason RP, Murray MW, Reash R, Saltman T, eds, Ecosystem Responses to Mercury Contamination: Indicators of Change. CRC, Boca Raton, FL, USA, pp 123-166.

57. Hoffman DJ, Ohlendorf HM, Marn CM, Pendleton GW. 1998 Association of mercury and selenium with altered glutathione metabolism and oxidative stress in diving ducks from the San Francisco Bay region, USA. Environ Toxicol Chem 17:167-172.

58. Henny CJ, Hill EF, Hoffman DJ, Spalding MG, Grove RA. 2002 Nineteenth century mercury: Hazard to wading birds and cormorants of the Carson River, Nevada. Ecotoxicology 11:213-231.

59. Hoffman DJ, Henny CJ, Hill EF, Grove RA, Kaiser JL, Stebbins KR. 2009. Mercury and drought along the lower Carson river, Nevada: III. Effects on blood and organ biochemistry and histopathology of snowy egrets and black-crowned night-herons on Lahontan Reservoir, 20022006. J Toxicol Environ Health A 72:1223-1241.

60. Wess J. 2004. Muscarinic acetylcholine receptor knockout mice: Novel phenotypes and clinical implications. Аппи Rev Pharmacol Toxicol 44:423-450.

61. Cheli V, Adrover M, Blanco C, Ferrari C, Cornea A, Pitossi F, Epstein AL, Jerusalinsky D. 2006. Knocking-down the NMDAR1 subunit in a limited amount of neurons in the rat hippocampus impairs learning. J Neurochem 97:68-73.

62. Basu N, Scheuhammer AM, Rouvinen-Watt K, Grochowina N, Evans RD, O'Brien M, Chan HM. 2007. Decreased N-methyl-D-aspartic acid (NMDA) receptor levels are associated with mercury exposure in wild and captive mink. Neurotoxicology 28:587-593.

63. Hoffman DJ, Spalding MG, Frederick PC. 2005. Subchronic effects of methylmercury on plasma and organ biochemistries in great egret nestlings. Environ Toxicol Chem 24:3078-3084.

64. Spalding MG, Bjork RD, Powell GVN, Sundlof SF. 1994. Mercury and cause of death in great white herons. $J$ Wildl Manag 58:735-739.

65. Ackerman JT, Eagles-Smith CA, Herzog MP. 2011. Bird mercury concentrations change rapidly as chicks age: Toxicological risk is highest at hatching and fledging. Environ Sci Technol 45:54185425.

66. Kamman NC, Burgess NM, Driscoll CT, Simonin HA, Goodale W, Linehan J, Estabrook R, Hutcheson M, Major A, Scheuhammer AM, Scruton DA. 2005. Mercury in freshwater fish of northeast North America-A geographic perspective based on fish tissue monitoring databases. Ecotoxicology 14:163-180.

67. Wiener JG, Sandheinrich MB, Bhavsar SP, Bohr JR, Evers DC, Monson BA, Schrank CS. 2012. Toxicological significance of mercury in yellow perch in the Laurentian Great Lakes region. Environ Pollut $161: 350-357$.

68. Sidor IF, Pokras MA, Major AR, Poppenga RH, Taylor KM, Miconi RM. 2003. Mortality of common loons in New England, 1987 to 2000. J Wildl Dis 39:306-315. 